\title{
Social Work and Community Based Disaster Risk Management in Pakistan
}

\author{
Sajjad Hussain \\ Department of Social Work \\ University of Malakand \\ Saira Miraj \\ Department of Social Work \\ University of Peshawar \\ Rani Saddique \\ Department of Psychology \\ University of Hazara
}

\begin{abstract}
Pakistan is exposed to various natural calamities due to its geophysical condition and climatic changes. In addition, man-made disasters also pose a threat to human lives and properties which includes industrial and transport disasters including oil spills, civil unrest, wars and conflicts. Although it is not possible to stop or prevent natural disasters, but the negative impacts of natural disasters can be minimized through human efforts. The government of Pakistan has adopted participatory approach as part of its policy for disaster management. This research paper is based on the analysis of secondary data for reviewing the existing policies with emphasis on disaster risk reduction in pre and post disaster period. The paper concludes that participation of target community is indispensable for disaster risk reduction on sustainable basis. The article suggests that community should be meaningfully involved in disaster risk reduction efforts at the local level. In this connection the role of social workers is indispensable for disaster risk reduction on sustainable basis.
\end{abstract}

Keywords: Disaster, Social Work, Community, Participation, Sustainability

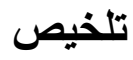

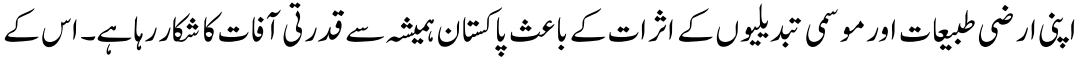

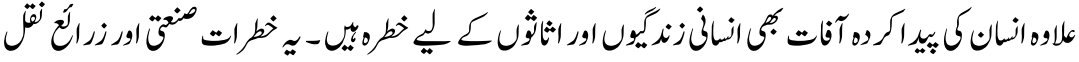

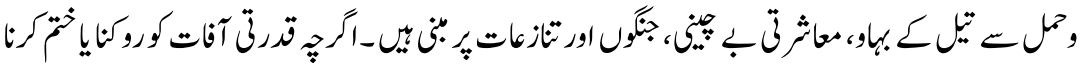

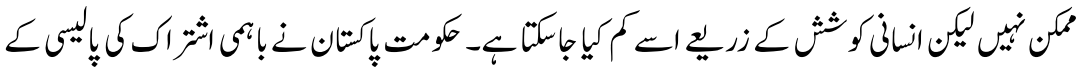

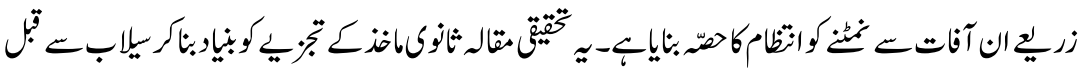

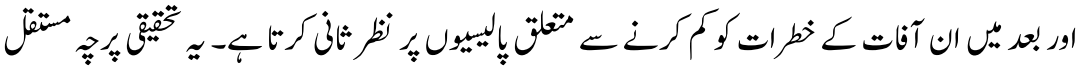




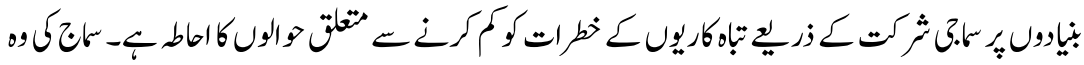

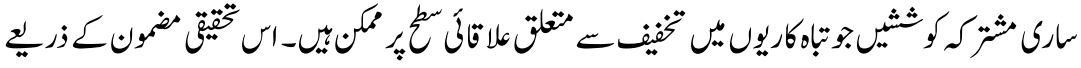

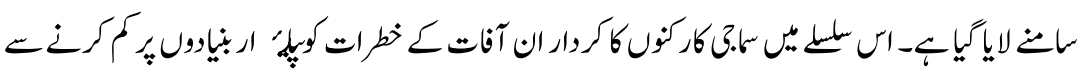

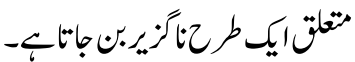

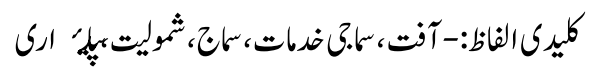

\section{Introduction}

Disaster is basically an unexpected and unfortunate happening which may causes damage to human beings as well as animals, plants and even livestock. Disaster occurs quickly, instantly and indiscriminately. Disasters may be natural or manmade which cannot be controlled, through human efforts and disrupt the normal functioning of society (Ashraf \& Shaha, 2016). These disastrous events accelerate the natural environmental processes to cause earthquakes, volcanic eruptions and extended dry conditions leading to long droughts, collision of celestial bodies, etc (Aziz, Saeed \& Waseem, 2016). Thus disaster is an event usually happening all of a sudden causing damage to lives, properties, environment and services which is beyond the control of the affected community and needs external support for assistance, response and rehabilitation. Disasters are natural phenomenon which subsisted with the human civilizations (Swathi, 2015). New inventions and technological advancements, detached man form natural elements on the one side and enlarged vulnerability of human to the disasters on the other hand (World Health Organization, 2015).

In disaster risk management context, a community can be taken as population residing in geographical areas, which is open to different calamities on account of their position. They may suffer hazards and disasters but still they have different opinions and vulnerability to risks. Thus people inside the vicinity will have stakes in risk reduction measure against or in favour (Tharoor, 2011).

The UN member countries struggle to minimize the disasters risks at a global level. In order to achieve this, Hyogo, Yokohama and the current of Sendai, all the three international conventions under the United Nations monitor the risks of the disasters internationally (McEntire 2007). In March 2015, members of the UN World Conference approved the Sendai Framework for Disaster Risk Reduction. This framework aimed at enhancing the capabilities of the countries by targeting the governance and accountability of all the stakeholders involved in the disaster risk management (Aitsi-Selmi; Egawa., Sasaki., Wannous \& Murray, 2015). This research is important in the Pakistani context because Pakistan has gone through several disasters in the past one and half decade that have resulted in heavy losses 
to humans and properties as well (Tozier de la Poterie \& Baudoin, 2015). During the disasters, it is the poor who are affected the most because of their vulnerable socio-economic conditions, and therefore, the social workers role to mitigate the damages in the scenario is of vital importance. Moreover, besides improving the life standards of these vulnerable communities, the social worker is also involved in the uplift of the individuals and communities' social structure.

The primary focus of this study is highlighting the role and involvement of professional social workers before and after the disaster hits a community. Because of being prepared and equipped for the crises situations, the social workers have the skills to effectively respond and participate in the relief and rehabilitation. Furthermore, the study aims to find out the damages caused by the disasters due to unpreparedness on the part of the community, as well as, the government in the past. The volunteers - mostly non-professional - although had worked hard to tackle the crises, but their unawareness and lack of skills resulted in little help and more wastage of time and resources.

\section{Community-Based Disaster Risk Management (CBDRM)}

Community based disaster risk management is a process to minimize the vulnerabilities and improve the capabilities of susceptible community through identification monitoring execution and evaluation of disaster risks. In other words, people are onboard in all the decisions and their implementation in disaster risk management activities (Atta-Ur-Rahman \& Shaw, 2015).

Like other South Asian Countries, Pakistan is also faced with natural disasters like flood, earthquakes, cyclones, landslides that pose a threat to human lives as well as properties (Fatima, 2016). There are various factors responsible for vulnerabilities of Pakistani society to hazards which include low standard construction practices, inadequate communication infrastructure along with the poor socio-economic conditions of people. However harsh climatic conditions and scattered settlement patterns of mountainous areas of Pakistan are more susceptible to disasters. So it is expected in the coming years that the intensity and frequency of hazards may rise which will have a great impact on economy and social aspects of the society. In addition, disasters are believed to be the major hurdles to sustainable development (Waseem, 2011).

\section{Literature Review An Overview of Major Disaster in Pakistan}

Pakistan is also at the danger of various types of natural disasters including cyclones, floods, landslides, earthquake and droughts are more common. Apart from natural disasters, Pakistan is facing many technological and man-made disasters. According to Yasuyuki, Bhattcharyay, \& Tomoaki, (2011) broadly, disasters can be divided in to the following main groups: 


\begin{tabular}{|l|l|}
\hline Groups & Sub Groups \\
\hline Natural Disasters & Earthquake \\
& Floods \\
& Storms \\
& Extreme Temperature \\
& Mass Movement \\
\hline Technological Disasters & Road Traffic Accidents \\
& Industrial Accidents \\
\hline Man Made Disasters & Terrorism \\
\hline
\end{tabular}

\section{Natural Disasters}

During the last few decades there has been enormous increase in disasters worldwide (Tharoor, 2011). As a result of these disasters 1,200,000 people were killed throughout the globe during the period of 2000 to 2012. These disasters affected half of the world population ( 2.9 billion) caused damage up to 1.7 trillion dollars. In addition, due to climatic changes, by the end of $19^{\text {th }}$ century world will get dangerously hot by an overall 1.4 degree Celsius (Mansoor, 2016).

Pakistan is also regularly facing natural disaster like floods, earthquake, heat-wave, droughts etc. These natural disasters have badly affected the economy and damaged the infrastructure, disrupted the livelihoods, services and health care (United Nations Economic and Social Commission for Asia and the Pacific, 2015). During the last five decades, in Pakistan 162 natural disasters occurred in the country. During the last 50 years, Pakistan faced 23 earthquakes resulting in heavy loss to humans while thousands were injured, homeless and economy also suffered (Swathi, 2015). In addition the earthquake of 2005 and the 2010-2011 floods caused destruction leaving thousands of people injured, dead and many became homeless. The estimated loss due to flood on infrastructure was about $\$ 4$ billion along with the total economic impact of $\$ 43$ billion for the country (SFCG, 2013).

\section{Technological Disasters}

Technological disasters i.e. industrial, transport accidents are happening frequently in Pakistan. Hundreds of people have been killed in train accidents and plan crashes. According to Khan and Jaferi (2016), 23 people died due to collision of trains in Karachi. The urban areas of Pakistan like Gujranwala, Faislabad, Karachi, Lahore, and Sialkot are also at the risk of industrial disasters due to increasing industrialization and lack of safety measures (Atta-Ur-Rahman \& Shaw, 2015). Karachi and Gawadar are two major ports of Pakistan which are also at risk of marine accidents. In august 2003, in Karachi, Greek old ship wreckage did big environmental losses; created health related issues for the nearby communities and also affected marine life as well by spilled out 28,000 ton of oil on the harbour area (National Disaster Management Authority, 2015). 


\section{Man-Made Disasters}

Man-made disasters can be defined as conditions that happen from a range of policy decisions and planned state actions which results in loss or damage to the physical and social infrastructure. Examples include war, internal strife, and brutal acts by rulers, epidemics and neo-liberal policies. These human-made disasters badly affect community driven development and results in loss to precious resources (Harding, 2007). According to McKay (2014), conflict is one of the greatest disasters that can strike any country and can lead to other types of disasters.

Pakistan has suffered a lot due to fighting war on terror since past one and half decade. Pakistani nation has suffered more than 80,000 causalities on account of terrorism alone, including Pakistan Army which suffered approximate 49000 lives from September 2001 to 2008 and later 15681 till date .Pakistan has suffered a total loss of about US\$ 100 billion/- in last 14 years of war on terror as against official losses of US\$ 68 billion in fiscal year 2010/11 due to military operations from September 2001 till date. The Pakistani nation has also gone through the most tragic incident of Army Public School Peshawar directly hitting the psychosocial fabric of Pakistani community (Kazmi \& Ali, 2015).

Man-made disasters include urban fires and civil conflicts:

\section{Urban Fires}

Due to increasing industrialization and urbanization, the population of cities are increasing day by day. The industrial units established in urban centres are not following the safety measures and as a result incidents like fires occurs (ADPC, 2015). Pakistan experienced the worst and largest industrial accidents in the history of textile industry on the evening of 11th September 2012, when the fire broke out in a garment factory located in SITE Industrial Area of Karachi, Sindh. The incident claimed 256 lives of skilled and unskilled worker and around 55 workers were injured among over 600 workers who were in the factory at the time of accident. The total number of the employees was 1500-2000 but the factory has no official data about the total number of employees as they were employed through contractor (Fatima, 2016). In addition, due to increasing numbers of CNG stations, sale of petroleum products in small shops coupled with smoking cigarettes can cause a major fire. Lack of awareness and education on the part of general public make them more susceptible to urban fires and other such incidents which can cause loss of lives and properties (Rafi, Wasiuddin, \& Siddiqui, 2012).

\section{Civil Conflicts}

During the past few decades, Pakistan has suffered a lot due to civil conflicts on the basis of ethnicity, religion and culture. During 1980s and 1990s, the conflicts 
resulted in heavy losses to lives, and properties creating feelings of insecurity in the affected areas. In addition Pakistan has also hosted 6 million refugees as result of Afghan war while about 2 million still live in various parts of Pakistan has badly affected the social and economic fabric of society (Waseem, 2011). According to Pakistan Institute for Peace Studies in 2013, 1200 hundred people died as results of sectarian violence while 80 Christians were killed in suicide attack on church in Peshawar. Due to the increasing numbers of attacks on religious minorities as well as rise in kidnapping, there have been feelings of insecurity among the general masses of Pakistan (Alam \& Noreen, 2014).

\section{Disaster Risk Management in Pakistan}

Government of Pakistan initiated Flood Control Program in the $4^{\text {th }}$ Five-Year Plan (1970-75) for the management of floods in the country. In 1974, Federal Emergency Relief Cell presented the draft of National Disaster Plan which described organizational hierarchy, processes, responding agencies, major responsibilities, procedures of monitoring relief operations. However, the plan could not be completed till 2005 (Kazmi \& Ali, 2015). Thus the traditional model of Disaster Risk Management Plan of relief and response has been followed for dealing with risk of natural disasters. Moreover West Pakistan National Calamities (Prevention and Relief) Act 1958 and Civil Defence Act 1952 were the first important legal instruments for organizing and coordinating the relief oriented model (Maqbool \& Hussain, 2014).

The October 2005 earthquake left Pakistan awe-struck and exposed the weaknesses of the present disaster and emergency management apparatus. The response to the earthquake of 2005 highlighted the importance of a national platform to effectively manage the DRR activities. To counter the flaws in the current program and to make it in line with International Covenants (UNISDR 2000 and Hyogo Framework for Action 2005-2015), National Disaster Management Ordinance (NDMO) was proclaimed in 2006. Subsequently in order to provide a national disaster framework, parliament enacted National Disaster Management (NDM) Act in 2010.

\section{National Disaster Risk Management Framework}

\section{National Disaster Management Commission}

National Disaster Management Commission (NDMC) led by the Prime Minister of Pakistan is considered as the national policy making body for managing disasters. Along with the Prime Minister, members of NDMC include Federal ministers, Leaders of opposition in National Assembly and Senate, all provinces Chief Ministers including Gilgit Baltistan, Prime Minister of AJK, Governor KP, civil society representatives, Chairman of Joint Chiefs Staff Committee, and any other member appointed by the Prime Minister (National Disaster Management Authority, 2015). 


\section{National Disaster Management Authority}

National Disaster Management Authority (NDMA) is the executive branch of the NDMC whose significant work is to coordinate and manage DRM activities at the national level. However they are responsible for developing guidelines used by provincial departments, federal ministries and district authorities for organizing DRM plans (Memon, 2012).

\section{Provincial Disaster Management Commissions}

Provincial Disaster Management Commissions (PDMC) was headed by respective Chief Minister, who is authorized to formulate policies, approve provincial plans and oversee the Disaster Risk Management. Its members include; leader of the opposition at the provincial legislature and one member nominated by him, rest of the members are to be nominated by the Chief Minister. The provincial commissions operate through the Provincial Disaster Management Authorities (PDMAs) (National Disaster Management Authority, 2015).

\section{Provincial Disaster Management Authorities (PDMA)}

PDMA coordinates with government line departments and District Management Authorities for planning and executing initiatives in emergency situations. Director General is assigned by the Provincial Government for looking after the administrative affairs of the authority (Bacha, 2016).

\section{District Disaster Management Authorities (DDMA)}

DDMA have been established at district level in all the provinces for implementing disaster management plans. Deputy Commissioners/District Coordination Officers have been assigned the responsibilities for planning, coordinating and execution of disaster management plans in the districts under the guidance of PDMAs (National Disaster Management Authority, 2011).

\section{Objectives of the Study}

The purpose of this paper is to examine the need and importance of community participation in Disaster Risk Reduction in Pakistan. The study also highlights the role of social work in increasing stakeholder participation in pre-and post- disaster period. Moreover, the study tries to find out the scale of the damage caused by the earthquake and floods; and the lack of skilled social workers, and insufficient response to these disasters by the ordinary individuals.

\section{Methodology}

This paper is qualitative in nature and extensive literature review has been carried out with the help of relevant government documents, research reports, journals 
and newspaper articles. In addition online sources were also utilized for getting up-dated information. This paper investigates the government's response to the 2005 earthquake that lead to the establishment of Earthquake Reconstruction and Rehabilitation Authority in October, 2005, and its subsequent relief, rescue and rehabilitation operations. Moreover, the role of the existing National Disaster Management Authority, established in 2007, has been reviewed in light of the available reports and other sources. The paper further investigates the operations of NDMA in response to the 2010 floods in Pakistan and examines the role of professional social workers before and after these calamities. The disaster management policies from 2005 - 2010 have also been analyzed in light of the published and online sources.

\section{CBDRM Conceptual Framework}

The government of various countries adopted disaster management strategies but those strategies mainly concentrated on relief and response. In addition, there was shortage of information regarding the methods involved in the determination of hazards, risk assessment, management and association of people's resources and disaster preparedness (United Nations, 2010). In addition, there was no framework for incorporating new ideas, scientific tools for efficient, cost effective and sustainable interventions (Rafiq \& Blaschke, 2012). Due to the inherent defects of relief and response strategy, the government of different countries adopted wideranging disaster management programs, stressing the needs for active participation of local people for decreasing the impacts of disaster to human lives, live stock and properties (United Nations, 2010). During the last few decades, disasters were considered as natural event and only government and NGOs responded without considering the social and economic implications of such events. Disaster risk reduction efforts were launched by the government officials without consulting the affected communities (Memon, 2012). This 'Top-Down' approach could not yield the desired results of disaster management as these were not according the needs of the target community and also ignored the available of the people. Such efforts made the communities more vulnerable to the disastrous situation. Due to the increasing dissatisfaction with the 'Top'-Down approach to disaster management, the national and international organizations are now using Bottom-up or participatory approach (Hossain,2013). Participatory development aims to launch disaster reduction efforts with the help of local people for viable results. The community based disaster risk management (CBDRM) approach believes in community mobilization and organization. The advocates of participatory approach consider that these are 'suitable strategies' for effectively dealing the dynamics and complexity of vulnerability and enhancing the capabilities of locals (Ashraf \& Shaha, 2016). During these changes in policy, it was realized that disaster mitigation calls for involvement of target community as these people were affected by the hazards and they responded as well. In addition the advocates of participatory approach believe that if the people of the vulnerable communities are properly guided and trained in the art of disaster mitigation, response and recovery, they will be better able to deal with disaster (Hossain, 2008). 


\section{State of CBDRM in Pakistan}

Pakistan has launched a number of Community Based Disaster Risk Management (CBDRM) initiatives since 2005. Since 2006, CBDRM has been made part of DRR programs both at the government as well as non-government organizations (NGOs). These organizations have adopted different methods and applied it in the community. However various NGOs have stressed on capacity building and social mobilization (Combaz, 2013). An all-inclusive approach in implementation of CBDRM calls for participation of all stakeholders at different stages of project cycle i.e. decision making, planning, implementation, monitoring and evaluation. This will lead to increase in resilience at the community subject to financial resources and better coordination. In addition CBDRM calls for a multi- dimensional approach which ought to fulfil various needs of the people affected by disasters which include development of physical infrastructure, improvement in economic resources and better livelihood (Rafi, Wasiuddin, \& Siddiqui, 2012). For instance, in Sindh a British NGO Disaster Emergency Committee (DEC) provided shelter, water and sanitation structure and increased people's capacity for dealing with emergency situations. Participation across the board also ensures identification of needs and mobilization of resources. Furthermore, cooperation and adaptive culture on the part of community is also integral for the viability of DDR activities (Shah 2013).

Community Based Disaster Risk Management (CBDRM) has certain advantages which distinguishes it from traditional approaches to DDR in Pakistan. CBDRM reduces the vulnerability to any disaster and therefore, overall disaster risk is decreased (Mansoor, 2016). Furthermore, it enhances resilience to disaster at grassroots level, and causes reduction in losses when disaster occurs. Likewise, it gives a new hope and fighting spirit which is essential for community in disaster situation (Bacha, 2016). Proper disaster risk reduction measures determine the empowerment of people in communities to reduce their vulnerability to hazard and also minimize its bad impacts. Involvement of all stakeholders in the DRR activities starting from decision making, planning, and implementation, and monitoring will create sense of ownership in the community which will lead them to the sustainability (World Health Organization, 2015).

The concept of disaster in literature is linked with deterioration by natural event. Social Work profession aims to rehabilitate those individuals, groups and communities who are affected either by natural or man-made disasters. Social workers perform important roles both in pre-and post -disaster period in accordance with the ethics of social work profession.

\section{Role of Social Workers in Enhancing Community Participation}

To promote social justice and get rid of discrimination and inequality is the basic aim of Social work profession. However, to deal with man-made disasters, social work profession must struggle for the provision of human rights through social work 
education and practices (Harding, 2007). Social Workers provide assistance to individuals, groups and communities in disasters. The role of social worker varies with the situations and may take the form of case work, group work and community organization (Tan, 2009). In this regard the study of Maripe \& Sinkamba (2015) in relation to the social work education and reduction of disaster risks in Botswana deducts that social workers' role in disaster risk reduction was more responsive than proactive, and was limited to natural disasters than relief provision (Revised National Policy on Destitute Persons, 2002). Likewise, Rapeli (2017) has concluded in his study in Finland regarding the social workers' role in disaster reduction; that the social workers displayed solid service linkages, for instance, in cases where the family had lost home in fire, or with the police in a case of a mass shooting.

The major areas in which social workers offer their services in disasters include dealing with traumatic stress, mobilization of resources for disadvantaged groups, psycho-social support to the affected people and social development using participatory approaches. Due to a major shift in the policies, there has been increasing demand for social workers in participatory disaster risk reduction. In Pakistan ensuing spontaneous contribution of the community in disaster danger reduction is the uphill task for social workers (Mathbor, 2007).

Social workers play an effective role in disaster management by mobilizing the available resources of the community with particular emphasis on empowerment of the poor people. Social worker can increase community participation by organizing the local people for the judicious utilization of their resources (Tan, 2009).

Another important duty of social worker is creation of awareness among the community people regarding their role at the time of disaster and to motivate, guide and train them how to respond in crises situation. The social worker can also ask the community to store necessary items like dry food, tents, first aid and medicine before a disaster strikes. In this way the damages and sufferings of the disaster affected people can be reduced (Hossain, 2013).

According to Maripe and Sinkamba (2015) social workers also provide mental health services to the affected people. They organize sessions with those who have passed through traumatic situations and are in shock. In general, the literature also brings-out the role of social work at micro-level responses to the individual effects by natural disasters. In a research study conducted by the American Red Cross concerning operations of the social workers in the United States of America, it was found out that about half of the mental health services during the disaster were carried out by the social workers affiliated with the American Red Cross and Federal Counselling Assistance and Training Programs (American Red Cross, 2016). 
Social workers can also arrange capacity building sessions for volunteers so that they can effectively deliver their services at the time of emergencies. They can also aware, educate and train the people of target community by showing drama, documentaries, and informal discussions for sharing information with the community people (Mathbor, 2007).

As every members of a specific community is not affected, therefore it is the duty of social workers to identify the most affected and vulnerable members of the community. In this way maximum and meaningful participation of the people can be ensured in disaster management plan. The social workers can also suggest the people not to depend on single occupation and adopt alternate occupations like combine farming through small business such as fishing, wage-labour, services etc (Laird, 2008).

Social Worker can play an effective role in mobilizing women of the target community keeping in view the socio-cultural conditions of the community. In this way the negative impacts of the disasters can be minimized and human lives, livestock, and properties can be protected from huge damages (Maripe, \& Sinkamba, 2015). It is important to make the disaster education as part of the curriculum in order to create awareness of the disaster risk reduction through the education system. In this connection Indonesian educator in social work Fahrudin (2012) and Nikku (2013) study in Nepal are very important as they stress on the need for social work education for the children to be guided, prepared and educated in the art of disaster preparedness.

\section{Conclusions}

The concept of community based disaster risk reduction was introduced as a result of the failure of traditional top-down approach in disaster management. These disaster management policies consist of community participation in all the levels of project cycle i.e. decision making, planning, implementation, monitoring and evaluation. In Pakistan, the role of social work is gaining recognition due to the increasing demand of social workers in emergency situations. The national and international organizations working in vulnerable communities in pre-and postdisaster period are hiring social workers for the rehabilitation of the affected people. These social workers are working as link between the target community and the implementing agencies. Professional social workers help the victims in traumatic situations; provide psycho-social support and designing strategies in pre-disaster period with the help of target communities. Social worker also organizes participatory assessment session using the rapid rural appraisal and participatory rural appraisal techniques for the identification of needs and resources of the communities. Social workers also link the target community with relevant government departments and donors for raising their issues and getting maximum assistance. Social workers also provide protection to the women and children particularly whose family members are missing as a result of catastrophe. 
Social workers assists the disable in disastrous situations by providing them assistive devices and refers them to relevant organizations for help. The role of social worker is much more important for mobilizing women as they constitute half of the population.

\section{Recommendations}

On the basis of the study, it is recommended that the community in general and vulnerable in particular should be meaningfully involved in the decision making, planning, implementation and monitoring of disaster management plans.

Before launching any interventions regarding disaster management, the government and non-governmental organizations should develop relationship with the target community so that the developmental organization may better know about the problems faced by the community in pre and post disaster period. As participation is indigenous in nature, therefore the people should be motivated for self- help initiatives for creating sense of ownership and sustained development. At the policy level, participation of target community should be made part and parcel of any intervention in disaster prone areas. Vibrant community organizations should be trained in disaster management, so that they can respond quickly in case of any disaster occurs.

The women of target community are also important stakeholders in the development process and equally deserve to take part in disaster management planning, implementation and monitoring. Social Work Departments at university level should equip the students with the necessary skills in disaster risk reduction. In addition, disaster management subject should be introduced both at the BS, MA, M.Phil and PhD level.

\section{References}

ADPC (2015). Community-Based Disaster Risk Management for Sindh Province. Asian Disaster Preparedness Center SM Tower, 24th Floor 979/69 Paholyothin Road SamsenNai, Phayathai, Bangkok 10400 Thailand. Web: www.adpc.net.

Aitsi-Selmi, A. \& Egawa, S. \& Sasaki, H. \& Wannous, C. \& Murray, V. (2015) The Sendai Framework for Disaster Risk Reduction: Renewing the Global Commitment to People's Resilience, Health, and Well-being. International Journal of Disaster Risk Science 6(2), 164-176.

Alam, F. \& Noreen, S. (2014). The Struggle against Religious Conflict in Pakistan. The Asia Foundation. Retrieved on July 24, 2017 from: http://asiafoundation.org/2014/08/06/the-struggle-against-religious-conflictin-pakistan/ 
American Red Cross. (2016). Retrieved November 4, 2016 from http://www.redcross.org/about-us/history/global-red-cross-network.

Ashraf, A. M. \& Shaha, B. S. (2016). Community Resilience: Case Study of Cyclone Aila Affected Coastal Bangladesh. International Journal of Social Work and Human Services Practice, vol.4:2, pp.33-41.

Atta-Ur-Rahman, Shaw R. (2015). Urban Risk and Reduction Approaches in Pakistan. In: Rahman AU., Khan A., Shaw R. (eds) Disaster Risk Reduction Approaches in Pakistan. Disaster Risk Reduction (Methods, Approaches and Practices). Springer, Tokyo.

Aziz, Saeed \& Waseem (2016). Need for Disaster Management in Pakistan: A Critical View. Journal of Information \& Communication Technology, vol.10:1, pp.58-64.

Bacha, A. (2016). Asian Disaster Reduction Centre Visiting Researcher Program - FY2016b Country Report: Islamic Republic of Pakistan. Retrieved on July 27, 2017 from: http://www.adrc.asia/countryreport/PAK/2016/ Pakistan_CR2016B.pdf

Combaz, E. (2013). Community-Based Disaster Risk Management in Pakistan (GSDRC Helpdesk Research Report 1028). Birmingham, UK: GSDRC, University of Birmingham.

Fahrudin, A.(2012).Preparing social work students for working with disaster survivors. Asian Social Work and Policy Review, 6, 86-94.

Fatima, F. (2016). Baldia Factory Fire Incident 4 Years of Successful Campaign for Justice. Retrieved on July 28, 2017 from: http://piler.org.pk/wpcontent/uploads/2017/02/Brief_Baldia_Factory_Fire-_Incident.pdf

Harding, S. (2007). Man-Made Disaster and Development: The Case of Iraq. International Social Work; 50; 295.

Hossain, M.A. (2013) Community Participation in Disaster Management: Role of Social Work to Enhance Participation. Journal of Anthropology, vol.9:1, pp.159-171.

Hossain, Md. A. (2008). Women's Participation in Social Change Decision: A Study of Two Union Parishads in Bangladesh. Unpublished M.Phil. Thesis, University of Bergen, Bergen, Norway.

Kazmi, N.S.S. \& Ali, A. (2015). Impacts of School Terrorism in the Milieu of Peshawar Incident; Pakistan's Black Day, December $16^{\text {th }}$ 2014. American Journal of Social Science Research, vol.1:4, pp.196-205. 
Khan, A. \& Jaferi, R. (2016, November 3). 22 Killed as Trains Collide Near Karachi's Landhi Railway Station. The Dawn. Retrieved on July 28, 2017 from: https://www.dawn.com/news/1294013

Laird, S. E. (2008). Social Work Practice to Support Survival Strategies in SubSaharan Africa. British Journal of Social Work, vol.38, pp.135-151.

McEntire, D. (2007) Local Emergency Management Organizations. In: Rodríguez, H. \& Quarantelli, E. L. \& Dynes, R. R. (Eds.) Handbook of Disaster Research. Springer, New York, pp.168-182.

Mansoor, H. (2016, June 21). Pakistan Faces Increasing Threats from Disasters, Warns NDMA Report. The Dawn. Retrieved on July 25, 2017 from: https://www.dawn.com/news/1266144

Maqbool, Y.M. \& Hussain, S. (2014). Institutionalization of Disaster Risk Management in Pakistan. ISSRA Papers, vol.6:II, pp.39-58. Retrieved on July 25, 2017 from: http://www.ndu.edu.pk/issra/issra_pub/articles/issrapaper/ISSRA Papers_Vol6_IssueII_2014/07-Institutionalization-ofDisaster-Risk- Muhammad-Yahhya-Maqbool.pdf

Maripe, M. K. \& Sinkamba, R. P. (2015). Social Work Education and Disaster Risk Reduction in Botswana. Asian Journal of Management Science and Economics, vol.2:1, pp.23-41

Mathbor, G. M. (2007). Enhancement of Community Preparedness for Natural Disasters. The Role of Social Work in Building Social Capital for Sustainable Disaster Relief and Management. International Social Work, vol.50:3, pp.357-369.

McKay, J. (2014). Man-Made Disasters: Are we paying attention? Hilal(2014 May). The Pakistan Armed Forces Magazine May, 2014. Retrieved on July 28, 2017 from: http://hilal.gov.pk/index.php/component/k2/item/391-manmade-disasters-are-we-paying-attention

Memon, N. (2012). Disasters in South Asia - A Regional Perspective. Pakistan Institute of Labour Education and Research PILER Centre, ST-001, Sector X, Sub-Sector V Gulshan-e-Maymar, Karachi, Pakistan.

National Disaster Management Authority (2011). Annual Report 2011. National Disaster Management Authority Prime Minister's Secretariat, Islamabad. www.ndma.gov.pk

National Disaster Management Authority (2015). Annual Report 2014-15. National Disaster Management Authority Prime Minister's Secretariat, Islamabad. Retrieved on July 23, 2017 from: http://www.ndma.gov.pk/ publications/AR2015.pdf 
Nikku, B. R. (2013). Children's Rights in Disasters: Concerns for Social WorkInsights from South Asia and Possible Lessons for Africa. International Social Work, vol.56, pp.51-66.

Rafi, M., Wasiuddin, S. \& Siddiqui, S. (2012). Assessment of Fire Hazard in Pakistan. Disaster Prevention and Management: An International Journal, vol.21:1, pp.71-84.

Rapeli,M .(2017). The Role of Social Work in Disaster Management in Finland. Department of Social Sciences and Philosophy, University of Jyväskylä Pekka Olsbo, Ville Korkiakangas Publishing Unit, University Library of Jyväskylä

Rafiq, L. \& Blaschke, T. (2012). Disaster Risk and Vulnerability in Pakistan at a District Level. Geomatics, Natural Hazards and Risk, vol.3:4, pp.324-341.

Revised National Policy on Destitute Persons. (2002). Gaborone: Government Press.

SFCG. (2013). Understanding the Dynamics of Conflict and Peace Building in Pakistan: A Perception Study. Search for Common Ground. Retrieved on July 28, 2017 from: https://www.sdpi.org/publications/files/Understanding $\% 20$ the $\% 20$ Dynamics $\% 20$ of $\% 20$ Conflict $\% 20$ and $\% 20$ Peacebuilding $\% 20 \mathrm{i}$ $\mathrm{n} \% 20$ Pakistan.pdf

Shah, S. H. (2013). The Disaster Risk Management Handbook. A Learning Experience of DRM Model Mansehra. Support to Governance in Pakistan Programme, with Deutsche Gesellschaftfür International Zusammenarbeit (GIZ). Retrieved on July 2, 2017 from: http://www.preventionweb.net/ files/32968_32968buildingresiliencebylearningth.pdf

Swati, M.J. (2015). Emergency and Disaster Reports: Monographic Issue the Profile of Disaster Risk of Pakistan and Institutional Response. Emergency and Disaster Reports, vol.2:1, pp.2-55.

Tan, N. T. (2009). Disaster Management: Strengths and Community Perspective. Journal of Global Social Work Practice, vol.2:1, pp.1-7.

Tharoor, I .(2011). Pakistan's Floods: Déjà vu, All Over Again, Time Magazine, (2011, September 14). Retrieved on July 25, 2017 from: http://world.time.com/2011/09/14/pakistans-floods-deja-vu-all-over-again/.

Tozier de la Poterie, A. and Baudoin, M.-A. (2015) From Yokohama to Sendai: Approaches to Participation in International Disaster Risk Reduction Frameworks. International Journal of Disaster Risk Science, vol.6, pp.128-139. 
United Nations (2010). Local Government \& Disaster Risk Reduction: Good Practices and Lessons Learned. Geneva: UNISDR.

United Nations Economic and Social Commission for Asia and the Pacific (ESCAP). (2015). Overview of Natural Disasters and their Impacts in Asia and the Pacific, 1970 - 2014. ESCAP Technical Paper Information and Communications Technology and Disaster Risk Reduction Division. Retrieved on July 25, 2017 from: http://www.unescap.org/sites/default/ files/Technical $\% 20$ paper-Overview $\% 20$ of $\% 20$ natural\%20hazards\%20and \%20their\%20impacts_final.pdf

Waseem, M. (2011). Patterns of Conflict in Pakistan: Implications for Policy. Working Paper Number 5. The Saban Centre for Middle East Policy at Brookings. Retrieved on July 27, 2017 from: https://www.brookings.edu/ wp-content/uploads/2016/06/01_pakistan_waseem.pdf

World Health Organization. (2015). Managing Disaster Risks in Communities. A Community-Based Approach to Disaster Risk Reduction (Training manual for the Trainers of Cluster Representatives and Volunteers). World Health Organization. Regional Office for the Eastern Mediterranean. ISBN: 97892-9021-906-4 ISBN: 978-92-9021-907-1 (online) (NLM Classification: WA 295. Retrieved on July 30, 2017 from:

Yasuyuki, S. Bhattcharyay, R. \& Tomoaki, K. (2011). Aggregate Impacts of Natural and Man-Made Disasters: A Quantitative Comparison. RIETI Discussion Paper Series 11-E-023. The Research Institute of Economy, Trade and Industry, http://www.rieti.go.jp/en/

Sajjad Hussain is Lecturer in the Department of Social Work, University of Malakand. Chakdara, Dir (Lower), Khyber Pakhtunkhwa Pakistan.

Saira Miraj is M.Phil Scholar in the Department of Social Work, University of Peshawar.

Rani Saddique is M.Phil Scholar in the Department of Psychology, University of Hazara. 